\title{
Properties of High-Strength Flowable Mortar Reinforced with Palm Fibers
}

\author{
Eethar Thanon Dawood ${ }^{1}$ and Mahyuddin Ramli ${ }^{2}$ \\ ${ }^{1}$ Construction and Building Department, Technical College of Mosul, Mosul, Iraq \\ ${ }^{2}$ School of Housing, Building \& Planning, Universiti Sains Malaysia, Penang, Malaysia \\ Correspondence should be addressed to Mahyuddin Ramli, mahyudin@usm.my
}

Received 13 September 2011; Accepted 18 October 2011

Academic Editors: M. Maslehuddin and I. G. Raftoyiannis

Copyright ( $) 2012$ E. T. Dawood and M. Ramli. This is an open access article distributed under the Creative Commons Attribution License, which permits unrestricted use, distribution, and reproduction in any medium, provided the original work is properly cited.

This study was conducted to determine some physical and mechanical properties of high-strength flowable mortar reinforced with different percentages of palm fiber $(0,0.2,0.4,0.6,0.8,1.0,1.2,1.4$, and $1.6 \%$ as volumetric fractions). The density, compressive strength, flexural strength, and toughness index were tested to determine the mechanical properties of this mortar. Test results illustrate that the inclusion of this fiber reduces the density of mortar. The use of $0.6 \%$ of palm fiber increases the compressive strength and flexural strength by about $15.1 \%$, and $16 \%$, respectively; besides, the toughness index $\left(\mathrm{I}_{5}\right)$ of the high-strength flowable mortar has been significantly enhanced by the use of $1 \%$ and more of palm fiber.

\section{Introduction}

High-strength concrete or mortar subjected to axial compression is known to be a brittle material with almost no strain-softening behavior. Adding fibers to plain matrix has little or no effect on its precracking behavior but does substantially enhance its postcracking response, which leads to a greatly improved toughness and impact behavior. The application of fibers in concrete was regarded very difficult in the past, due to insufficient workability of fiber reinforced mixtures. The development of superplasticizer has proven to offer significant improvement in application of fibers like in slabs and floors, shell domes, rock slope stabilization, refractory linings, composite metal decks, seismic retrofitting, repair and rehabilitation of structure, fire protection coatings, concrete pipes and [1]. Over the last three decades, fiber-reinforced concrete (FRC) has been the subject of many investigations. Researches have been performed on the behavior of fiber-reinforced concrete subjected to various types of loading and incorporating different fibers ranging from steel, glass, plastic, and natural fibers in various sizes and shapes [2].

Natural fibers have the potential to be used as reinforcement to overcome the inherent deficiencies in cementitious materials. In recent years, there has been sustained interest in utilizing natural fibers in cement composites and in manufacturing products based on them with a view to have alternate building materials, which are energy efficient, economical, and ecofriendly. If the function of natural fibres in a relatively brittle cement matrix is to achieve and maintain toughness and ductility of the composite, then, the durability of such fibres in a highly alkaline cement matrix must be taken into consideration and ensured by effective modifications made either to the fibre surface or to the matrix composition to overcome the inherent problem $[3,4]$. The objectives of the present work was to investigate the effects of palm fiber with different volume fractions on the properties of high-strength flowable mortar.

\section{Materials and Mix Proportions}

2.1. Materials. The cement used in mortar mixtures was ordinary Portland cement a product of (Tasek Corporation Berhad). Silica fume product (Scancem Materials Sdn. Bhd.) was used as partial replacement of cement in different percentages in this study to determine the optimum percentage of replacement. The chemical compositions of 
TABle 1: Chemical composition of Ordinary Portland cement and silica fume.

\begin{tabular}{lcc}
\hline Constituent & $\begin{array}{c}\text { Ordinary Portland Cement } \\
\text { \% by weight }\end{array}$ & $\begin{array}{c}\text { Silica fume } \\
\% \text { by weight }\end{array}$ \\
\hline Lime $(\mathrm{CaO})$ & 64.64 & $1.0 \%(\max )$ \\
Silica $\left(\mathrm{SiO}_{2}\right)$ & 21.28 & $90 \%(\max )$ \\
Alumina $\left(\mathrm{Al}_{2} \mathrm{O}_{3}\right)$ & 5.60 & $1.2 \%(\max )$ \\
Iron Oxide $\left(\mathrm{Fe}_{2} \mathrm{O}_{3}\right)$ & 3.36 & $2.0 \%(\max )$ \\
Magnesia $(\mathrm{MgO})$ & 2.06 & $0.6 \%(\max )$ \\
Sulphur Trioxide $\left(\mathrm{SO}_{3}\right)$ & 2.14 & $0.5 \%(\max )$ \\
$\mathrm{N}_{2} \mathrm{O}$ & 0.05 & $0.8 \%(\max )$ \\
Loss of Ignition & 0.64 & $6 \%(\max )$ \\
Lime saturation factor & 0.92 & - \\
$\mathrm{C} 3 \mathrm{~S}$ & 52.82 & - \\
C2S & 21.45 & - \\
C3A & 9.16 & - \\
C4AF & 10.2 & - \\
\hline
\end{tabular}

TABLe 2: Characteristics of palm fiber.

\begin{tabular}{lc}
\hline Fiber properties & Quantity \\
\hline Average fiber length, mm & 30 \\
Average fiber width, microne & 21.13 \\
Tensile strength $(\mathrm{MPa})$ & 21.2 \\
Elongation at break (\%) & 0.04 \\
Specific gravity & 1.24 \\
Water absorption \%, 24/48 hrs & 0.6 \\
\hline
\end{tabular}

Ordinary Portland and silica fume are given in Table 1. The superplasticizer (SP) (Conplast SP1000, Fosroc Sdn. Bhd.) was used at $2 \%$ to give the properties of desirable flowability for all mixes. The fine aggregate used is natural sand, whose fineness modulus is 2.86 and the maximum size is less than $5 \mathrm{~mm}$. The palm fiber is produced by Fiber-X (M) Sdn. Bhd, and its characteristics are shown in Table 2.

2.2. Mix Proportions. Approximate concrete composition is given in Table 3. The mixture is designed according to the absolute volume method given by ACI [5]. The palm fiber of the volumetric fractions $0.2,0.4,0.6,0.8,1.0,1.2,1.4$, and $1.6 \%$ of the mixes were used in preparing mixes M1-M8.

\section{Test Methods}

Three cube samples $50 \mathrm{~mm}$ were used for each mix to test of density and compressive strength after water curing (26 \pm $2{ }^{\circ} \mathrm{C}$ ) condition until the age of test. The flow test for mixes was performed according to ASTM C230 [6]. The flow design for all mixes was $\geq 110 \mathrm{~mm}$. The cube specimens were left in the molds for 24 hours at $20^{\circ} \mathrm{C}$. After demolding, the specimens were kept in water curing till the age of test $(28$ days). The test of saturated surface dry of specimens at the age of test was adopted and implemented according to BS 1881: Part 114 [7].The test of compressive strength was

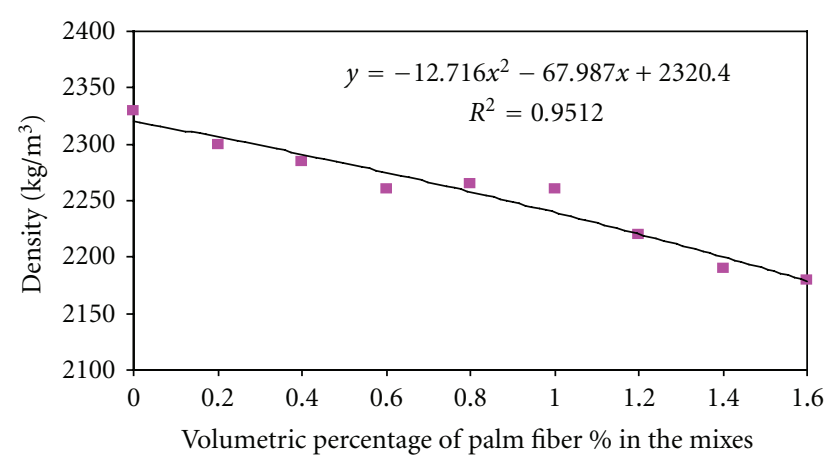

FIGURE 1: Relation between fiber content and saturated surface dry density at 28 days.

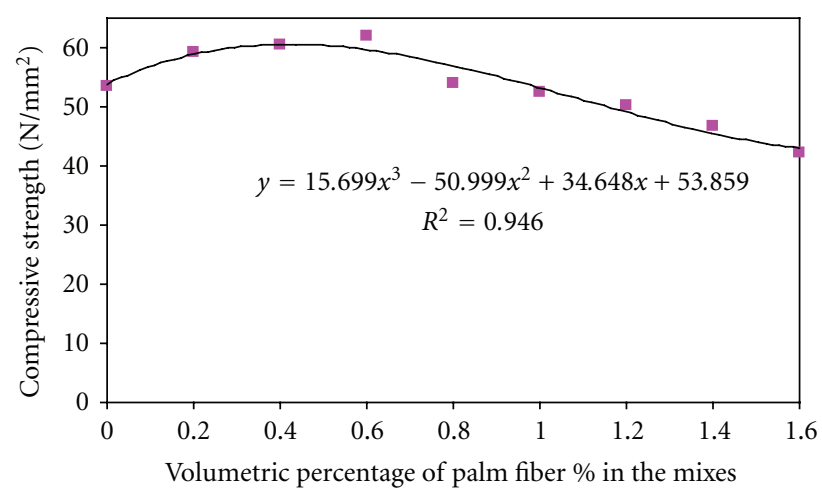

FIGURE 2: Relation between fiber content and Compressive strength at 28 days.

achieved directly after the density test according to ASTM C109 [6] for each test age. Besides, the prismatic steel molds $(40 \times 40 \times 160 \mathrm{~mm})$ were used for the flexural strength test according to ASTM C348 [6] and the Toughness index according to ASTM C1018 [6].

\section{Results and Discussion}

4.1. Saturated-Surface-Dry Density. Table 4 shows the results of the saturated surface dry density for all mixes, and from the results, it can be noticed that the inclusion of palm fiber in the mortar mixes decreases the hardened density, and this can be attributed to the specific gravity of fiber which reduce the overall density of mortar as shown in Figure 1 [8-10].

4.2. Compressive Strength. From Table 4, it can be concluded that the increase of palm fiber increases the compressive strength due to the reduction of porosity in the mortar mixes till $0.6 \%$ of fiber as volumetric fraction of the mix. But beyond this fraction, the compressive strength reduces clearly and this can be attributed to the air voids and disintegration with the excessive fiber use in the mixes $[10,11]$. From Figures 2 and 3, it can be observed clearly that the increase of fiber from $0 \%$ to $0.6 \%$ increases the compressive strength by about $16.1 \%$ in spite of the decrease in density, but beyond that fraction the usual relation between density and 
TABLE 3: Mortar mixes proportions.

\begin{tabular}{lcccccccc}
\hline Index & $\begin{array}{c}\text { Cement } \\
\mathrm{Kg} / \mathrm{m}^{3}\end{array}$ & $\begin{array}{c}\text { Silica fume } \\
\mathrm{Kg} / \mathrm{m}^{3}\end{array}$ & $\begin{array}{c}\text { Water } \\
\mathrm{Kg} / \mathrm{m}^{3}\end{array}$ & $\begin{array}{c}\text { Sp. } \\
\mathrm{Kg} / \mathrm{m}^{3}\end{array}$ & $\begin{array}{c}\text { Sand } \\
\mathrm{Kg} / \mathrm{m}^{3}\end{array}$ & W/B & $\begin{array}{c}\text { palm fiber } \\
\text { volumetric fraction \% }\end{array}$ & $\begin{array}{c}\text { Flow } \\
\mathrm{mm}\end{array}$ \\
\hline M0 & 550 & 40 & 240 & 11.8 & 1415 & 0.43 & 0 & 140 \\
M1 & 550 & 40 & 240 & 11.8 & 1415 & 0.43 & 0.2 & 130 \\
M2 & 550 & 40 & 240 & 11.8 & 1415 & 0.43 & 0.4 & 125 \\
M3 & 545 & 40 & 240 & 11.8 & 1405 & 0.43 & 0.6 & 125 \\
M4 & 545 & 40 & 240 & 11.8 & 1405 & 0.43 & 0.8 & 120 \\
M5 & 540 & 40 & 240 & 11.8 & 1390 & 0.43 & 1.0 & 115 \\
M6 & 540 & 40 & 240 & 11.8 & 1390 & 0.43 & 1.2 & 120 \\
M7 & 535 & 40 & 240 & 11.8 & 1380 & 0.43 & 1.4 & 115 \\
M8 & 535 & 40 & 240 & 11.8 & 1380 & 0.43 & 1.6 & 110 \\
\hline
\end{tabular}

TABle 4: Mechanical properties of mortar mixes.

\begin{tabular}{lccccccc}
\hline Index & $\begin{array}{c}\text { Density } \\
\mathrm{Kg} / \mathrm{m}^{3}(7 \text { days })\end{array}$ & $\begin{array}{c}\text { Compressive strength } \\
(\mathrm{MPa})(7 \text { days })\end{array}$ & $\begin{array}{c}\text { Flexural strength } \\
(\mathrm{MPa})(7 \text { days })\end{array}$ & $\begin{array}{c}\text { Density } \\
\mathrm{Kg} / \mathrm{m}^{3}(28 \text { days })\end{array}$ & $\begin{array}{c}\text { Compressive strength } \\
(\mathrm{MPa})(28 \text { days })\end{array}$ & $\begin{array}{c}\text { Flexural strength } \\
(\mathrm{MPa})(28 \text { days })\end{array}$ & $\begin{array}{c}\text { Toughness } \\
\text { Index } \mathrm{I}_{5}\end{array}$ \\
\hline M0 & 2300 & 42.1 & 6.52 & 2330 & 53.5 & 7.6 & 1.0 \\
M1 & 2260 & 46.3 & 6.88 & 2300 & 59.2 & 7.97 & 1.0 \\
M2 & 2250 & 47.1 & 7.11 & 2285 & 60.4 & 8.28 & 1.0 \\
M3 & 2240 & 47.9 & 7.54 & 2260 & 62.1 & 8.75 & 1.0 \\
M4 & 2240 & 44.3 & 6.88 & 2265 & 54.1 & 7.9 & 1.0 \\
M5 & 2235 & 42.3 & 5.94 & 2260 & 52.4 & 6.95 & 1.29 \\
M6 & 2210 & 41.4 & 5.33 & 2220 & 50.2 & 6.45 & 1.42 \\
M7 & 2180 & 33.7 & 5.35 & 2190 & 46.7 & 6.36 & 1.55 \\
M8 & 2175 & 29.1 & 4.88 & 2180 & 42.2 & 5.93 & 1.77 \\
\hline
\end{tabular}

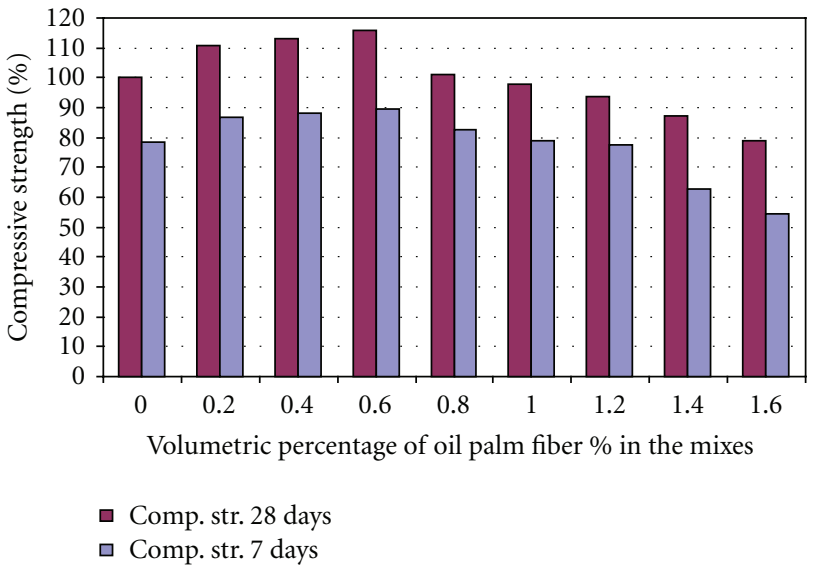

FIGURE 3: Relation between fiber content and compressive strength percentage.

compressive strength can be noticed. Figure 4 illustrates the relation of compressive strength and density for the fiber flowable high-strength mortar at 28 days.

4.3. Flexural Strength. The flexural strength of the highstrength flowable mortar mixes is shown in Table 4.The increase of the flexural strength is compatible with the compressive strength increase, and also, Figures 5 and 6

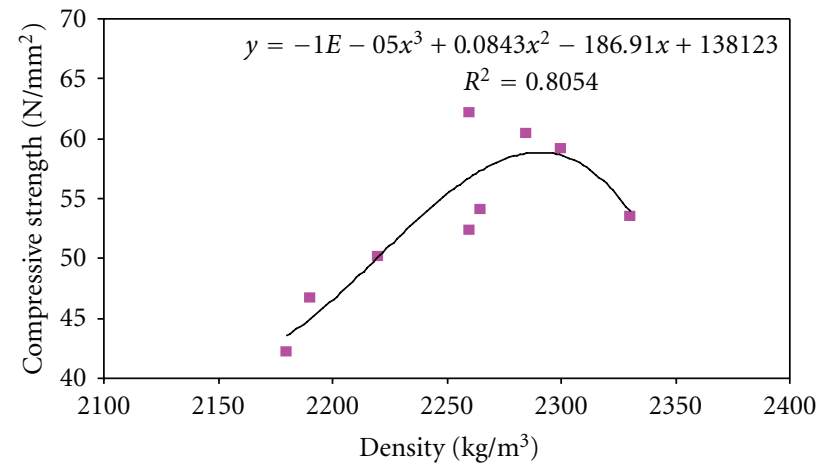

Figure 4: Relation between compressive strength and density at 28 days.

illustrate the increase of the flexural strength till $0.6 \%$ volumetric fraction of palm fiber in the mix and beyond this percentage the decrease in flexural strength can be noticed due to the same former causes listed in Compressive Strength. The relation between compressive strength and flexural strength is shown clearly in Figure 7.

4.4. Toughness Index. Toughness is also defined as energy absorption capacity. The toughness index can be determined according to ASTM C1018. The indices $\mathrm{I}_{5}, \mathrm{I}_{10}$, and $\mathrm{I}_{30}$ can be calculated from this test where the ratio of the area under 


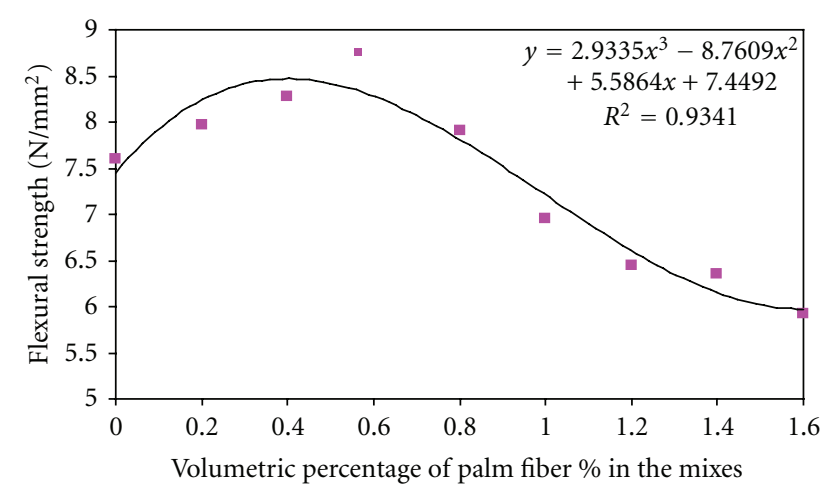

Figure 5: Relation between fiber content and flexural strength at 28 days.

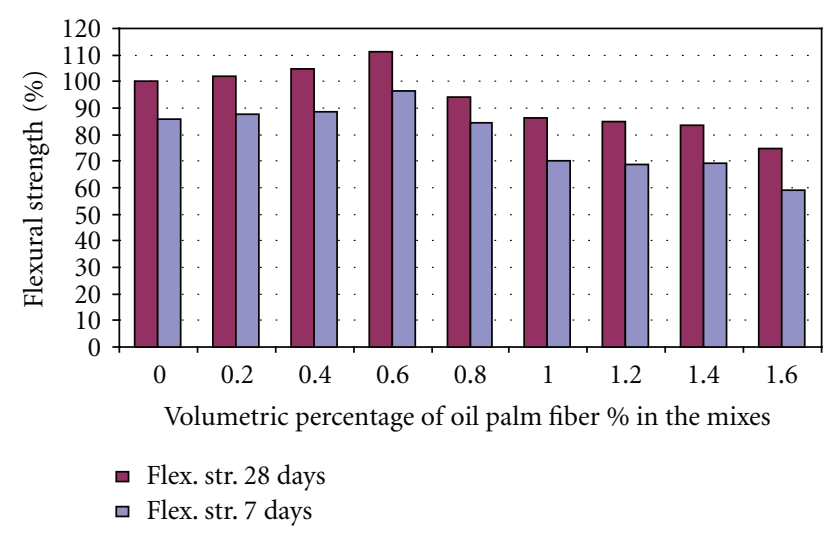

Figure 6: Relation between fiber content and flexural strength percentage.

the load deflection curve is up to $3,5.5$, and 15.5 times the first crack deflection, divided by the area up to the first crack deflection, respectively, as shown in Figure 8.

Table 4 illustrates the results of the $\mathrm{I}_{5}$. It can be observed that the fiber fraction up to $0.8 \%$ has no effect on the toughness index but it has increased as the fiber fraction increased too. Therefore, the increase for the toughness should require higher volume fraction than $0.8 \%$, but taking into consideration the effect of using that on the other properties of the high-strength flowable mortar [11].

\section{Conclusions}

Some conclusions from this study can be revealed as follows.

(1) The use of palm fiber has clear effects on the properties of high-strength flowable mortar.

(2) The flowability of the mortar is affected slightly by the inclusion of the palm fiber in the mixes, and this may help to use this fiber in the field of flowable mortar applications.

(3) The use of palm fiber reduces the density, and this may be considered as a significant factor if it is

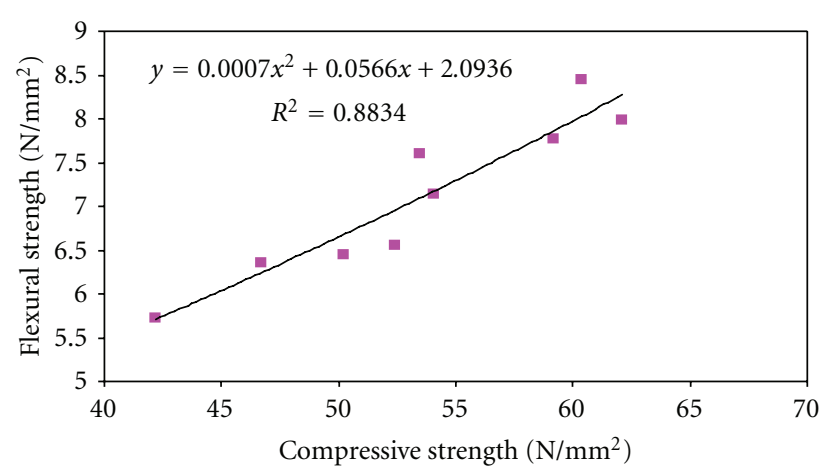

Figure 7: Relation between and Compressive strength and Flexural strength at 28 days.

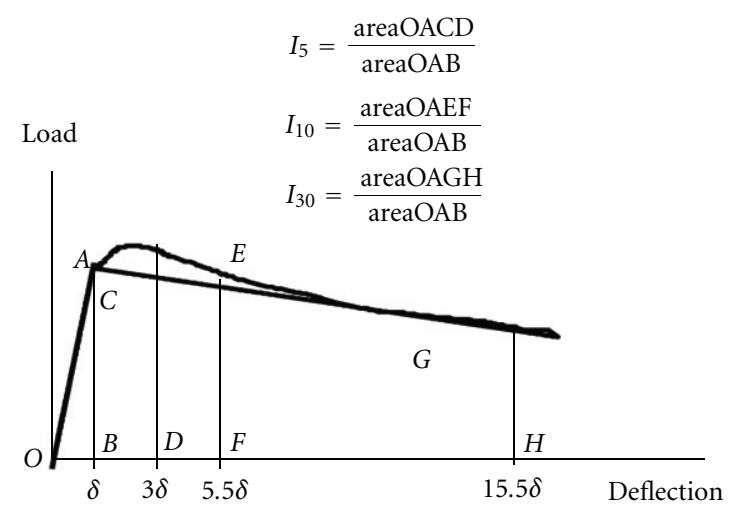

FIgURE 8: Toughness indices according to the testing method ASTM C1018.

compatible with acceptable ranges of compressive strength.

(4) The compressive strength results show that the use of $0.6 \%$ of the palm fiber as volumetric fraction increases the strength by about $16 \%$, but beyond this percentage there is a clear decrease in compressive reaches about $21 \%$ using $1.6 \%$ of fiber volumetric fraction.

(5) The flexural strength results show that the use of $0.6 \%$ of the palm fiber as volumetric fraction increases the strength by about $11 \%$ and again beyond this percentage there is a decrease in flexural strength by about $24 \%$ using $1.6 \%$ of fiber volumetric fraction.

(6) The toughness results illustrate that the use of $0.8 \%$ and more of palm fiber has an effect in improving the toughness index $\left(I_{5}\right)$; therefore, the development of the ductility and the absorption capacity of the mortar can be expected by only using the percentage of $0.8 \%$ or more of palm fibers. 


\section{Disclosure}

The paper has not been previously published, is not currently submitted for review to any other journal, and will not be submitted elsewhere before a decision is made by this journal.

\section{References}

[1] R. F. Toledo, K. Ghavami, G. L. England, and K. Scrivener, "Development of vegetable fibre-mortar composites of improved durability," Cement \& Concrete Composites, vol. 25, no. 2, pp. 185-196, 2003.

[2] S. K. Al-Oraimi and A. C. Seibi, Mechanical Characterization and Impact Behavior of Concrete Reinforced with Natura Lfibers, College of enginnering, Sultan Qabos University, Muscat, Oman, 1995.

[3] K. Bilba, M. A. Arsene, and A. Ouensanga, "Sugar cane bagasse fibre reinforced cement composites. Part I. Influence of the botanical components of bagasse on the setting of bagasse/cement composite," Cement \& Concrete Composites, vol. 25, no. 1, pp. 91-96, 2003.

[4] G. Ramakrishna and T. Sundararajan, "Impact Strength of a few natural fiber reinforced cement mortar slabs: a comparative study," Cement \& Concrete Composites, vol. 27, pp. 547-553, 2005, Department of Civil Engineering College, Pondicherry Engineering College, Pondicherry, India.

[5] ACI 213R, American Concrete Institute, "Guide for structural lightweight aggregate concrete," Farmington Hills, Mich, USA, http://www.concrete.org/.

[6] ASTM C 138, C173 ,C330 and C 567, C143 \& C567,C1018, "Annual book of ASTM Standard ,Volume 04.02," ASTM international, West Conshohocken, Pa, USA, http://www.astm .org/.

[7] British Standard, "Methods for determination of density of hardened concrete," BS 1881, Part 1 14, 1983.

[8] E. T. Dawood and M. Ramli, "Development of high strength flowable mortar with hybrid fiber," Construction and Building Materials, vol. 24, no. 6, pp. 1043-1050, 2010.

[9] A. M. Neville, Properties of Concrete, 4th edition, 1995.

[10] M. Ramli and T. Dawood, "Behavior of flowable high strength concrete repair materials for sustainable engineering construction," in Proceedings of the 2nd International Conference on Built Environment in Developing Countries (ICBEDC '08), pp. 444-460, School of Housing, Building and Planning, USM, Penang, Malaysia, 2008.

[11] E. T. Dawood and M. Ramli, "High strength characteristics of cement mortar reinforced with hybrid fibres," Construction and Building Materials, vol. 25, no. 5, pp. 2240-2247, 2011. 

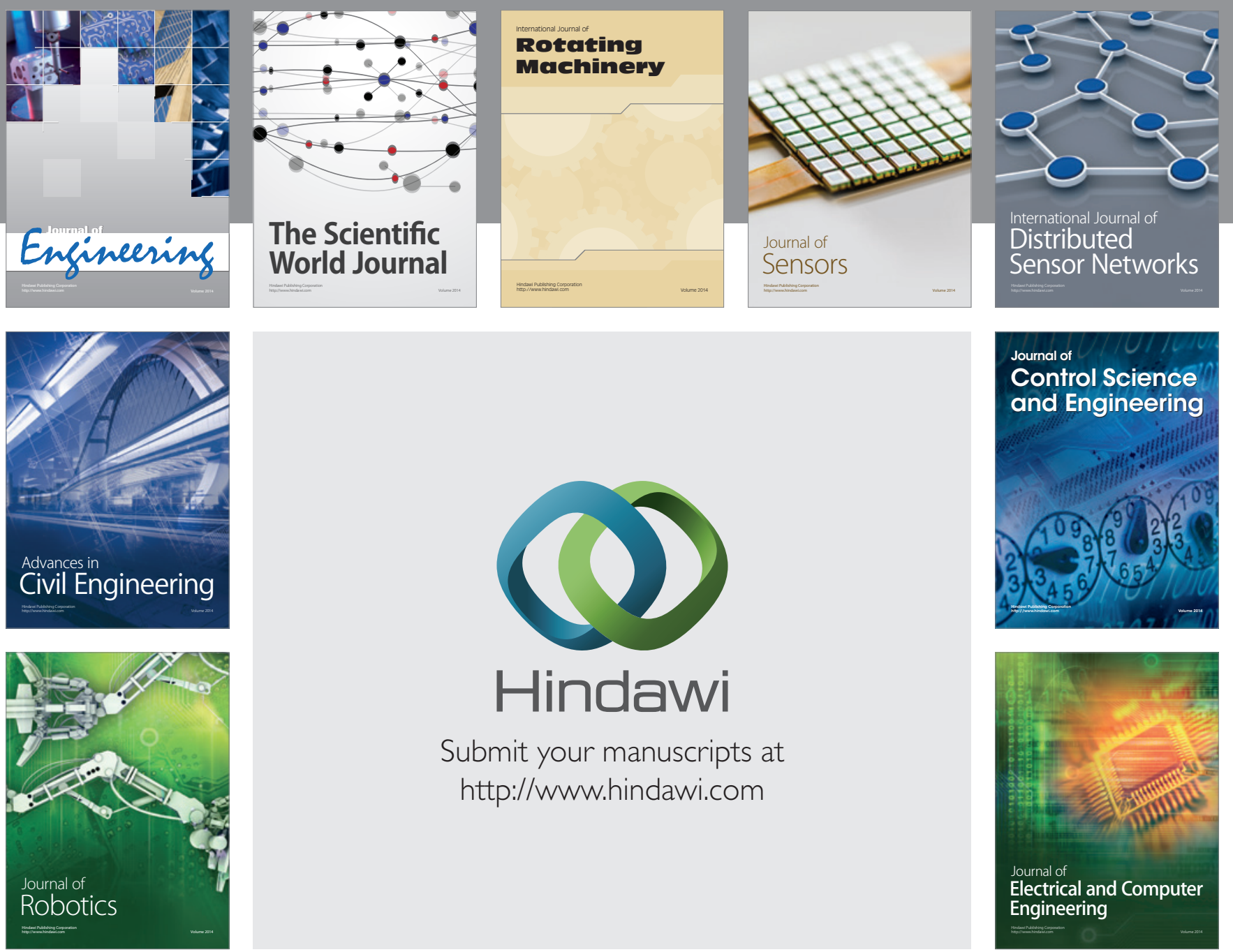

Submit your manuscripts at

http://www.hindawi.com
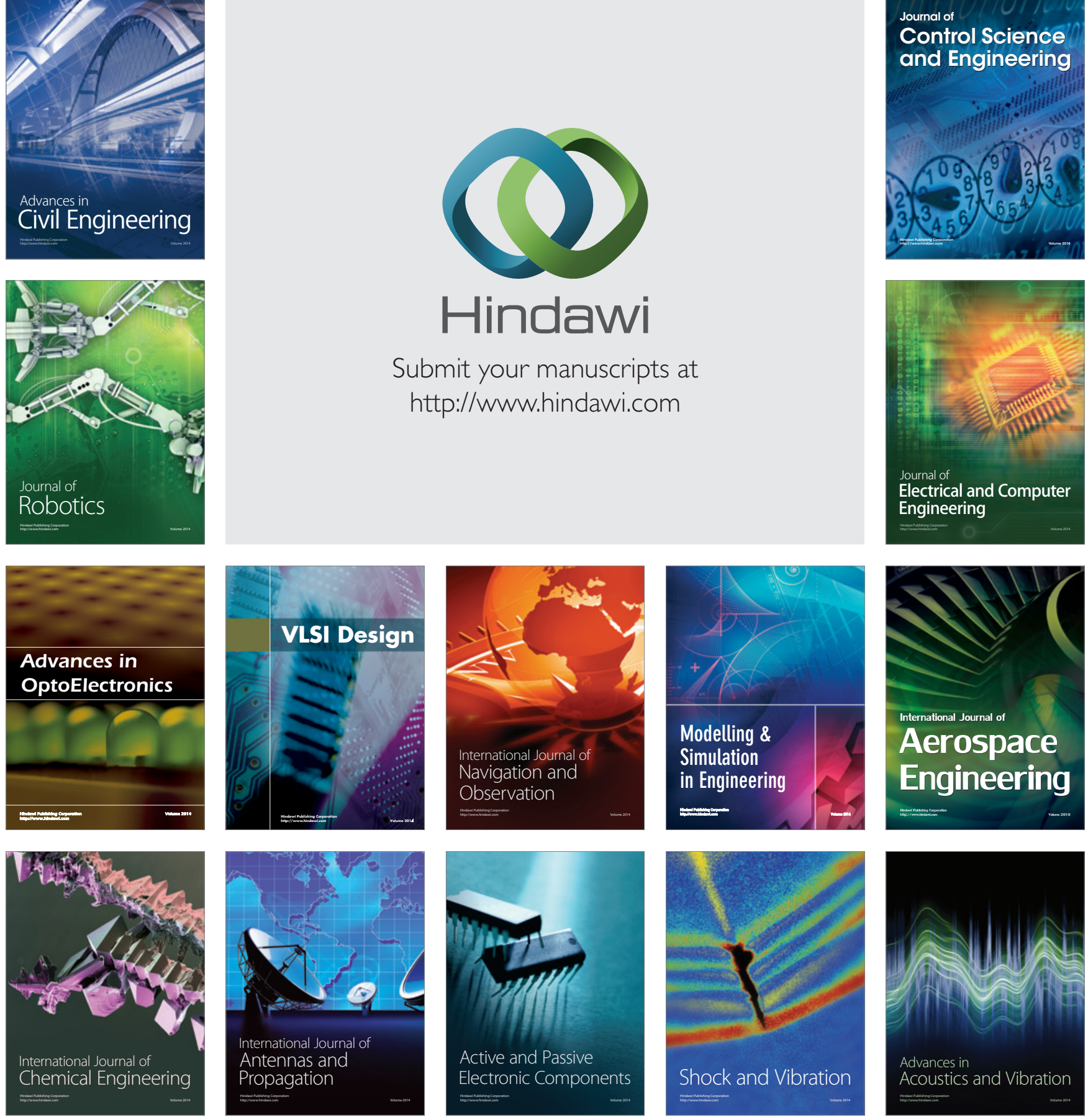